\title{
Van ebben valami végzetes
}

\section{Ferge Zsuzsa: Már a vízben tanultam meg úszni}

Ma Magyarországon normatív alapon senki nem kap segélyt, csak az önkormányzatok adnak ötletszerüen annak, aki nagyon kér. Holott a segélyt egyéni kérelemhez kötni Európában ma már súlyosan meghaladott álláspont. Ehelyett egyre terjed a társadalmi alapjövedelem gondolata, amit viszont idehaza elvetnek. Van ebben valami végzetes - íme a ma 90. születésnapját ünneplő Ferge Zsuzsa gondolatai, akivel nem csak a jelenről, hanem a múltról is beszélgettünk, a kezdetekről, Solt Ottiliáról, a szociális képzés hazai megteremtéséről.

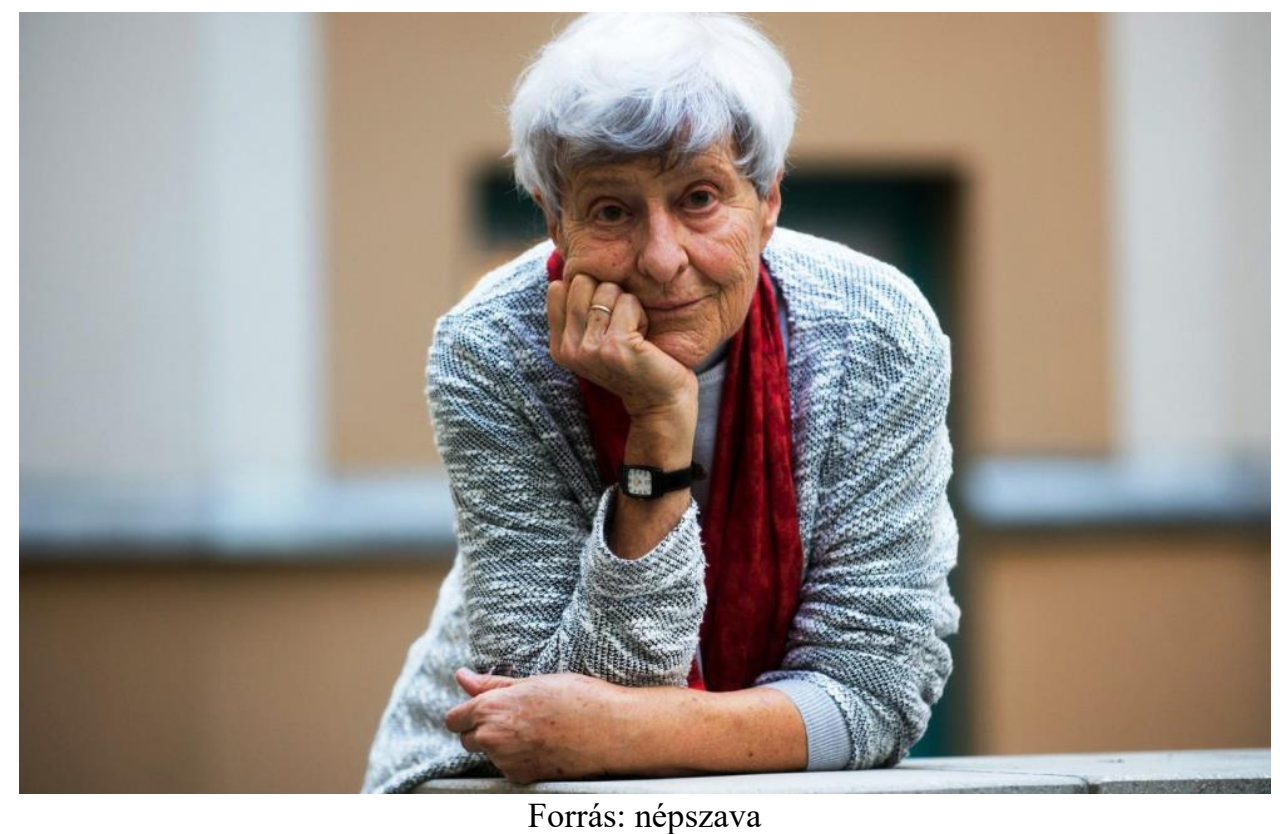

Volt egy megfogható pillanat az életedben, amikor elkezdtél gondolkodni a társadalmi egyenlötlenségeken, a kirekesztésen? Egyáltalán, ez valamiféle tudatos döntés eredménye volt, vagy egy folyamat?

Ez egy nagyon hosszú folyamat volt, amely azzal kezdődik, hogy zsidó vagyok. Ennek következtében az apámat megölték 1944-ben, ahogy a nagyszüleimet is megölték 1944ben. Ekkor én két évre Franciaországba kerültem, és amikor visszajöttem, osztottam annak lelkesedését, hogy itt most valami nagyon más következik. Ide tartozik, hogy Franciaországban egy nagyon előkelő Versailles-i gimnáziumban voltam idegen nyelvü, franciául nem tudó zsidó, és ebben a közegben nem igazán kedvelték az idegeneket. Tehát ez a kirekesztettség vagy nevezzük kisebbségi létnek, elevenen élt bennem, voltaképp a háború előtt észleltem, de a tragédia fölerősítette bennem. Amikor visszajöttem Magyarországra, akkor úgy éreztem, hogy ennek most itt vége, része vagyok az egésznek. Ez nem tartott sokáig, talán egy éven át. 1950-ben ugyanis szinte minden egyetemen 
megcsinálták a maguk kis Rajk-perét, ahol én jártam, a Marx Károly Közgazdaságtudományin pedig rám esett a választás, én lettem a mintaper vádlottja. Ideális alany voltam, a felvételin Széchenyi mellett érveltem Kossuth ellenében, Franciaországból jöttem, matematikaképzőt szerveztem. Viszont akkor ismerkedtem össze a férjemmel, és a következő negyven évet együtt éltük le. És együtt dolgoztuk át, mert az akkori élmény, vagyis az egyenlötlenség-probléma mindkettőnké volt, s az egész életünk azzal telt, hogy a magunk hatókörében mindent megtegyünk ellene. A férjem a Pénzügyminisztériumban dolgozott a költségvetési föosztályon, s nagyon fontos szerepe volt abban, hogy progresszív jövedelemadó legyen, ami az egyenlötlenségek csökkentésének az egyetlen állami eszköze. Ez 2010 után megszünt.

Nem merült föl benned a koncepciós perek időszakában, hogy kár volt Franciaországból eljönni és talán el kéne innen menekülni?

1956-ban már mindkét gyerekünk megszületett, a második gyerek ráadásul még nagyon piciny volt. Gondolkoztunk rajta, de a férjem nem tudott nyelveket, neki nagyon nehéz lett volna beilleszkedni, pláne két gyerekkel. Maradtunk.

A maradás ára az volt, hogy lényegében büntetésként kellett a KSH háztartás-statisztikai osztályán dolgoznod. Több interjúdban is felidézed, hogy tulajdonképpen itt szembesültél elöször a kor propagandájával, azzal, hogyan csürik-csavarják a számokat.

Tulajdonképpen óriási szerencsém volt, hogy megbüntettek ezzel a bizonyos szempontból valóban alantas háztartás-statisztikával, mert volt ott úgy kétezer háztartási könyv, s ezekböl rengeteg adatot ki tudtam gyüjteni. Az első ilyen adatok a gyerekekre vonatkoztak, és valami olyasmiről szóltak, hogy a gyerekek egy részének nincs asztaluk, amin megírják a leckéjüket és nem kapnak eleget enni sem. Ez mélyen megrázott. Ráadásul Solt Ottilia is a KSH-ba került, s kis ideig együtt dolgoztunk, és ő mindent föltett a szegénység csökkentésére, $\mathrm{s}$ a gondolkodása rányomta a bélyegét az én további munkámra is. Otti, szegény, nagyon fiatalon meghalt, de a gondolkodása, a szellemisége, az, hogy méltóságot és megélhetést kell teremteni mindenkinek, velem maradt.

Csak az 1960-as években lett az MTA-nak Szociológiai Kutatóintézete. Magadat is körülbelül ezzel egyidőben azonositottad szociológusként?

Én egyike vagyok azoknak, akik nem is tudják, hogy prózában beszélnek. De a viccet félretéve, fogalmam sem volt arról, hogy mi is az a szociológia. Ezen akkor kezdtem valójában gondolkodni, amikor a hatvanas években Párizsban találkoztam Raymond Aronnal, akinek az intézetéből később a nagy, híres Bourdieau-intézet lett, úgyhogy már a hatvanas évek elején találkoztam jelentékeny francia szociológusokkal, köztük Bourdieau-vel is. Ekkor tudatosodott bennem, hogy amit csinálok, amin gondolkodom, az valójában szociológia, és ekkor kezdtem el olvasni a klasszikusokat is. A módszert statisztikusként tudtam, azzal tehát nem volt problémám. De a szociológia gondolatrendszerét, elméleteit ekkor tanultam meg, amikor már műveltem a szakmát. Ha úgy tetszik, már a vízben tanultam meg úszni. 
Mikor érezted azt, hogy a szociológiából egy másik irányzat felé mozditod el a hazai tudományos életet is azzal, hogy megalapitod a Szociálpolitika Tanszéket az ELTE-n? És egyáltalán, hogyan kristályosodott ki benned, hogy szükség van az ilyen típusú egyetemi oktatásra is?

Lényegében óriási szerencsém volt, mert Szalai Sándor, aki az ELTE-n tanított, kiküldött egy világkongresszusra, ahol találkozhattam azzal a Peter Townsenddel, aki Angliában szegénységkutatásokat szervezett. Egyfajta kormányzati tanácsadóként rengeteg kormányjavaslatot dolgozott ki, és megtisztelt azzal, hogy elhívott Angliába. Ott láttam számos olyan egyetemet, ahol volt szociálpolitikai kar. Ebböl fölmértem, hogy mekkora tudásanyag halmozódott föl szociálpolitikában, és rájöttem, mekkora tévedés csak az állami költségvetés egyetlen tételeként gondolni a szociálpolitikára, hiszen a társadalompolitika valóban átfogja a társadalom egészét, miközben alapvetően befolyásolja annak értékrendjét és tartalmát egyaránt. Ha pedig ez így van, akkor ezt érdemes Magyarországon is komolyan venni. Az egyetem természetesen ezt nem hitte el nekem. Pontosan nem is emlékszem, hogy mikor kezdödött el ez a küzdelem, miniszterekhez jártam, s szerencsére Huszár Tibort viszonylag hamar sikerült magam mellé állítani. Végül is neki köszönhető az, hogy lett Szociálpolitika Tanszék. Ez hosszú küzdelem volt, a tanszék valamikor a nyolcvanas években alakult meg. Utóbb összefonódott vele a szociálismunkás-képzés is, s jó, hogy ez így alakult, s most vannak képzett szociális szakemberek Magyarországon. Hogy később mi lesz, az már más kérdés.

Hegyesi Gábor egy tanulmányában felvillantotta, hogy egy időben azt hangoztattad, a szociális munka csak sebtapasz, ami megakadályozza a fertözést, de strukturális válaszokat nem ad. Később azonban meggyözödtél arról, hogy dehogynem, személyes szolgáltatásokkal megváltoztatható az egyén helyzete, ami kihathat a strukturális problémákra is. Milyen tapasztalatok vezettek el oda, hogy a szociális munkát és a szociálpolitikát már szövetségben látod?

Valóban rengeteg változáson mentem át. Először tényleg azt gondoltam, hogy a szociális munka nem old meg semmit - vagy csak nagyon keveset old meg. Aztán fokozatosan két dologra jöttem rá. Az egyik az, hogy az egyes embernek iszonyatosan nagy szüksége lehet arra, hogy valamilyen személyes segítséget kapjon, továbbá, hogy a szociális munka komolyan vétele és társadalmi erőforrásnak tekintése tulajdonképpen az emberek fölértékelését is magával hozza, vagyis, némi pátosszal bár, de javítja a társadalmat. Igen, először valóban azt gondoltam, hogy a szociális munka müvi beavatkozás, ami helyett jobb lenne, ha az emberek lakást, pénzt és mindenféle személyes szolgáltatást kapnának, és tudják ök azt maguktól is, hogy mire van szükségük, ehhez nem igazán kell szociális munkás. De aztán fokozatosan rájöttem, hogy ez nem egészen van így, az egyénnel és a családjával komplex módon kell foglalkozni, és ez időnként külső segítség nélkül nem megy. Tehát azt, hogy az erőforrásokat hogyan lehet megszervezni és felhasználni, nem mindenki tanulja meg otthon, mert odahaza is meg vannak fosztva azoktól a lehetőségektől, amelyek az erőforrások megszerzését szolgálnák. A külső segítség pedig inspiráló is lehet, információkat nyújtó, együttmüködő, ami már partnerséget is jelent. Vagyis a jó szociális munka, ha úgy tetszik, nem a szegényeket segíti, hanem a polgárokat segíti abban, hogy polgárok legyenek. 
Egyszer azt nyilatkoztad, hogy a magyar társadalomban hol van, hol nincs szociálpolitika. Az elmúlt évtizedekben, mikor volt értelmezhetö és hatékony szociálpolitika, és mikor volt érzékelhetö ennek a hiánya?

Úgy látom, hogy a Gyurcsány-korszak alatt volt négy-öt olyan év, amikor úgy tűnt, hogy a miniszterelnököt valóban foglalkoztatja ez a dolog, és igyekszik tenni is valamit a helyzet javítása érdekében. Tulajdonképpen az addigi pénzkivonások helyett inkább még tettek is a rendszerbe, és kezdett átalakulni a segélyezés gondolatrendszere is úgy, hogy ahhoz jogok is kapcsolódjanak. Magyarországon nagyon új - és eretnek - gondolat, hogy a szegény embereknek jogaik is legyenek. És hát le is csengett ez az időszak, 2010 óta jelentős romlást érzékelek. A forráskivonás a szociális szférából és az egészségügyből egészen dermesztő, miként a teljes jogbizonytalanság is. A hajléktalanok utcáról törvénnyel való kitiltása, mikor más helyük nincs, felfoghatatlan. Miközben látjuk, hogy a Covid-halálozások magas számának igenis van köze az orvos- és ápolóhiányhoz. Vagyis van tétje annak, hogy a modern állam mennyit költ az egészségügyre. Korábban a nemzeti össztermék úgy 5-6 százalékát költöttük erre, ez az arány ma az 5 százalékot sem éri el.

2007-ben elfogadott a parlament egy nagyon fontos dokumentumot, a Legyen jobb a gyermekeknek! nemzeti stratégiát. Ez különleges pillanat volt.

Az akadémiai kutatóintézetben dolgozó csoport minden tagja együttesen vett részt a Nógrádban, azon belül Szécsényben zajló programban, ahol megpróbáltuk kipróbálni a gyakorlatban mindazt, amit korábban elméletben végiggondoltunk. De nem juthattunk a végére: az új kormány létrejötte után egy szerdai napon szóltak, hogy csütörtökön ürítsük ki a szobát. Így lett vége ennek a csoportnak. Vele együtt a gyerek- és gyerekjólétkutatásnak is, meg annak is, hogy megpróbáljunk tenni valamit ezen a szinten. A szociálpolitika dolga az, hogy a társadalmi egyenlötlenségeket csökkentse, de 2010 után megszüntették a progresszív adózást, a gyermekellátást pedig úgy változtatták meg, hogy ami mindenkinek jár, a családi pótlék, változatlan marad, még az árakhoz sem igazodik. Az igénybe vehető támogatásokat, például a CSOK-ot pedig, azok kapják, akik közt szegények már nincsenek is. A kormány középosztály-erösítő politikát folytat, ami önmagában nem lenne baj, de ez együtt jár azzal, hogy a szegényektől elvon.

Arról beszéltél Zsuzsa egyszer, hogy szorongsz, mert annyira elszegényitett és gyülölettöl terhes országgá kezdünk válni, ami miatt a jövö generációjának nagyon nehéz lesz. Nem érzed úgy, hogy ez a szorongás valamiféleképp már régóta velünk van? Kis János ezt úgy fogalmazta meg, hogy ez százéves háború, amelyben nem legyözni kell a másikat, hanem megsemmisiteni, és a rendszerváltás után sem a demokrácia, hanem ez a felfogás uralkodott el fölöttünk.

Nagyon nehéz másképp látni ezt. Holott vannak szerencsésebb országok, Bulgária, Hollandia és a skandináv országok még arra is képesek voltak, hogy a zsidógyülöletnek és a zsidók elpusztításának ellenálljanak, pedig az kötelező volt valamennyi, Hitler befolyása alatt lévő országban. Magyarországon ez a fajta ellenállás soha nem volt meg, a kisebbségekkel szembeni elöítéletek, azt hiszem, mindig is léteztek, az antiszemitizmus 
nagyon-nagyon régi, de nemcsak antiszemitizmusról van már szó, hanem sajnos migránsellenességről, az országon csak áthaladó idegenek gyülöletéről is. Ez utóbbiban a kormánynak rendkívül súlyos szerepe van. A menekülőknek még az étkeztetését sem hajlandók tisztességesen megoldani. Sosem túl erősen ugyan, de valamikor még élő gondolat volt, hogy az idegenek is emberek, s most úgy tünik, hogy a kormányzati politikák ezzel szembe mennek, ami fájdalmas és szomorú is egyben, és kihat a társadalom erkölcsi színvonalára is.

A '80-as években, amikor elindult az egyetemi képzés, s ezzel egyidöben sorra alakultak a civilszervezetek. Zsuzsa, több tanulmányodban is kiálltál amellett, hogy a civilek kiegészitenek bizonyos állami szolgáltatásokat, miközben azt is láttad, hogy ez a civilszektor igen gyengécske. Nem hozhatja-e el e mostani szabadsághiányos állapot, hogy megerösödjön alulról szervezödve a civil szféra, miután az állammal kapcsolatban egy csomó illúzióval leszámoltunk?

Úgy tünik, hogy ez a kormány nem kedveli a függetlenséget, mondjuk úgy, hogy autonómiaellenes. Ez veszélyezteti a civileket is. Nézzünk csak a Magyar Tudományos Akadémiával történtekre. A tudás támadása autonómiaellenes, a tudásgyüjtő, felhalmozó, megosztó intézmények gyengítése is az, s mindez fokozatosan, de egyre nagyobb tömegben történik. E sorozat lényeges állomása az MTA tulajdonképpeni megszüntetése, az intézmények elvétele, tulajdonképpen az egész tudomány- és iskolarendszer átszervezése. Amennyire én tudom, a társadalomnak viszonylag egy kis része, azt hiszem, egyötöde az, amely aktív a civil szektorban, ami nagyon alacsony ahhoz képest, amit, mondjuk, jobb országokban lehet látni. És az is biztos, hogy a kormány válogat a civilszervezetek között. Tehát létrehoz olyanokat, amelyek az ő szája íze szerint müködnek, nekik pénzt is ad, amit megtagad azoktól a szervezetektől, amelyeknek az autonómiájával, céljaival nem ért egyet. Azok, akikkel én valamikor együtt dolgoztam, időnként kiszorulnak a lehetőségekből, bár most talán megint újraszerveződik valami a szegények érdekében, de nagyon nehéz itt átlátni, hogy meddig lehet elmenni, és hol van az a határ, amelynél a kormány úgy gondolja, hogy az már túl sok az autonómiából, legyen szó akár szegényekről, akár a cigányság ügyéröl. Ez utóbbi különösen fontos csoport: pontosan nem lehet tudni, hány roma ember él Magyarországon, én valahol félmillió fölé teszem a számukat. Amikor minden roma dolgozott, akkor elkezdődött egy nagyon jelentős integrációs folyamat, ami megtört: ma oly mértékü a kettészakadás, ami szinte kezelhetetlen, kiváltképp úgy, hogy egyre erősödik a kormány által is táplált kiszorítás. Ma a roma kisebbség helyzete részben javul ugyan, de nagyobbrészt romlik, ami természetesen összefügg azzal, hogy a jogszerü segélyezést teljesen megszüntették. Ma Magyarországon normatív alapon senki nem kap segélyt, csak az önkormányzatok adnak ötletszerüen annak, aki nagyon kér. Holott a segélyt egyéni kérelemhez kötni Európában ma már súlyosan meghaladott álláspont. Ehelyett egyre terjed a társadalmi alapjövedelem gondolata, amit viszont idehaza elvetnek. 